\title{
Comparison and Economic Feasibility Study of The Productivity of Five Varieties of Barley (Hordeum vulgare L.)
}

\author{
Mahmod Karem Ahmad \\ Department of Agriculture Extension \\ Bakrajo Technical Institute \\ Sulaimani Polytechnic University \\ Sulaimani, Iraq \\ mahmodkarem1954@Gmail.com
}

\begin{abstract}
In general, economic and agricultural policy of the successive Iraqi governments was not toward agricultural development and achieve food security, whether for humans or animals, for dependence on exports of oil to import country's food needs in a difficult currency, which cost the state budget amounts. Scientific and technological underdevelopment, lack of feasibility studies, economic performance,customs, social traditions, religious beliefs and neglect of the farmer caused a lack of interest in the cultivation of barley and its selection of high quality and quantity varieties of grains,straw,land, storage, and marketing operations.The study was conducted to assess the economic feasibility of the productivity of the five Asian barley varieties (Hordeum vulgare L.), (Arivat, Norma ,Iba99, NS313 andBip999) for grain and straw yield in Bakrajo area during the winter season of (2015 -2016). The results showed that grain and straw yield parameters were significantly varied according to varieties. Significant increase in grain yield $(2720 \mathrm{~kg} / \mathrm{ha})$, hay yield $(3643 \mathrm{~kg} / \mathrm{ha})$, grain and hay cost (736.180)1000ID/ha, hay revenue (582.880) 1000ID/ha, grain revenue (1019.997)1000ID/ha, profit (866.697)1000ID/ha, seed product (27.200) $\mathrm{kg}$ and $1000 I D$ income (2.221) were recorded for NS313 and Bip999 varieties, while the number of grains / spike (44.133) and plant length (89.433) $\mathrm{cm}$ was recorded for Iba99 variety.
\end{abstract}

Keywords: Economic, Feasibility, Barley, Grain, Straw, Profit.

\section{INTRODUCTION}

Barley (Hordeum vulgare L.) is an important grain crop grown in wide areas in the world. It was ranked among grains in quantity produced (144 million tons) in the world behind rice and wheat in 2014 [1] in 2015, barley was ranked among grains in quantity produced (thousand tons in Iraq after rice and wheat). The cultivated area for 2015 was estimated (1003) thousand ton. Yield average of one hectare was estimated (1315) $\mathrm{kg}$ of a total cultivated area for winter season 2015. Straw production of the barley was estimated (515) thousand ton for 2015 [2]. It has played an important role in ancient Kurdish cultures as a staple bread-making, as well as grain and straw an important food for animals. Barley was also considered as a cheaper option for poor families as an important feed grain in many areas of the world [3]. Barley is a key ingredient in beer and Whisky production it improves cholesterol and glucose regulation [4]. It's one of the important cereal crops in the Kurdistan region of Iraq, during the dry winter season it grows successfully in a wide range of climate than any other cereals. It gives the highest yield of grain and straw for farmers filed in rain condition of the Kurdistan region. In the Kurdistan region in 2013 only (84170) hectares of land was under barley cultivation, where the production is only (135183) tons with the average yield of $(1606 \mathrm{~kg} / \mathrm{ha})$. The area, yield and production of barley in governorates of Kurdistan region during the winter season 2012-2013, Sulaimani recorded the highest cultivated area (36603)/ha. Erbil ranks second (34285)/ha and Duhok recorded lowest cultivated area (13282)/ha. Erbil and Duhok recorded the highest yield/ha (1729) kg/ha and (1581) kg/ha while Sulaimani recorded the lowest yield (1500) $\mathrm{kg} / \mathrm{ha}$. In terms of the grain production in ton, Erbil recorded the highest grain production (59279) ton. Sulaimani ranks second grain production (54905) ton and Duhok recorded the lowest grain production (20999) ton. Sulaimani recorded the highest straw yield/ha (3302) kg/ha. Duhok ranks second hay yield/ha (3129) kg/ha. The lowest governorate in the yield/ha was Erbil (2798.4) kg/ha. Regarding straw production, Sulaimani recorded the highest hay production (120863) ton. Erbil ranks second straw production (95943) ton. The lowest hay production (41562) ton was in Duhok. In the same time, straw production in governorates of Kurdistan region during the season (2012-2013) was (258368) tons of straw with an average yield $(3069.6 \mathrm{~kg} / \mathrm{ha})$. In the same year 2013, in Sulaimani governorate (36603) hectares of land was under barley cultivation where the production was only (54905) tons, with the average yield of (1500 $\mathrm{kg} / \mathrm{ha}$ ) and (120863) tons of straw with average yield of (3302 kg/ha) [5].

In Kurdistan region, the crop is sown with the minimum care and management under residual moisture, proper land preparation, application of fertilizer, irrigation, optimum time of sowing, seed rate which are not usually practiced in ruining this crop. Most of the Kurdish farmer's neglect using the right scientific ways in serving the land, plan for production, storage, and 
marketing. The total economic value of the grain for human consumption and straws for animal feed this so called total crop value [6]. The economic and nutritional value of straw for feed is a function of both its quantity and quality [7]. Indeed, farmers in some tropical and temperate cropping systems prefer to burn straw rather than to harvest it $[8,9]$. The global production of rain has increased dramatically over recent decades through higher yields per unit area and an expanded area under cultivation [10]. Implicit in this process is that traditional grazing lands are being encroached on for crop production that fallow periods have shortened, and that the world production of crop by-products is increasing $[11,12]$. All these actors affect the feed supply for ruminants. In turn, these animals provide arange of essential functions for farmers in many farming systems, e.g., draught, dung, security, income. The use of straws and grazing for animal feed has received ample attention from the scientific community. A particularly wide range of chemical treatment and supplementation methods have been examined with varying degrees of success to overcome the nutritional limitations of these 'byproducts' and thus improve farmers livelihoods $[13,14,15,16,17,18,19]$ and $[20,21,22,23,24]$. In addition, cereal crop breeders respond to farmers' demands by increasingly considering the economic value of straws in plant breeding objectives. Therefore, it is necessary to increase our understanding of the economic rationale of feeding straws, or, in other words, to better assess the economic value of straw in relation to grain production. The aim of this study was to encourage the increase of barley production horizontally and vertically and interest in collecting straw instead of leaving it or burning it in the field.

\section{METHODS AND MATERIALS}

The experiment was conducted at the research farm of the Bakrajo Technical Agricultural Institute belongs to Sulaimani Polytechnic University, Kurdistan Region, Iraq, which is located (11) Km west of Sulaimani center with an altitude of $(847 \mathrm{~m})$ above sea level, and lies between 35032-36 north latitude and 45o21-09.6 east longitude. The soil in the experimental field was sandyclay-loam, under rain-fed condition during the winter growing season of (2015-2016). The experiment was laid out in Randomized Complete Block Design (RCBD) with a net plot area $\left(2.5 \mathrm{~m}^{2}\right), 5$ rows per plot, the density between rows $20 \mathrm{~cm}$. The experiment comprised of five barley varieties treatments, Arivat, Norma, Iba99, NS313 and Bip999 was applied with three replications. Barley cultivars were sown with a hand drill on 28th November 2015, using a rate of $100 \mathrm{~kg} / \mathrm{ha}$, (25 g/plot) ( $5 \mathrm{~g} / \mathrm{row})$. Standard cultural practices were done for the field of experiment. The field was kept weed-free throughout the dropping period and other standard cultural practices were followed to raise the crop. Observations were recorded on 10 randomly selected plants for plant height $(\mathrm{cm})$, number of fertile tillers, spike length $(\mathrm{cm})$, average spike weight $(\mathrm{g})$, number of grains/spikes, grain weight/spike (g), and 1000 grain weight $(\mathrm{g})$. While grain and straw yield were calculated based on plots harvested in June from $\left(1 \mathrm{~m}^{2}\right)$. Costs were taken from Kurdistan region statistics office report (2014). The price of buying and selling the grain and straw was taken from an old farmer in the local markets. The data was subjected to statistical analyses in (RCBD) using (XLSTAT) computer program and means were compared by Duncan's multiple range test at $\mathrm{p} \leq 0.05$ prospects [25].

\section{RESULTS AND DISCUSSION}

Data represented in the table (1) shows the grain yield of the tested varieties were significantly different. NS313 recorded the highest grain yield $(2720 \mathrm{~kg} / \mathrm{ha})$ significantly from other varieties except for Bip999, while variety, Arivat recorded significantly the lowest yield (1898 g/ha). Regarding the weight of 1000 grains and grain weight per spike, there were no significant differences among the varieties. It is clear from table (2) that no significant differences appeared among the studied varieties concerning spike length and spike weight. In this study, the trait No. of grains/spike was only significantly affected by varieties. Iba99 significantly surpassed other varieties (44.133) and Norma was recorded the lowest number of grains/spike (35.800).

Table 1: Means for grain yield, the weight of 1000 grains and grain weight/spike.

\begin{tabular}{cccc}
\hline Varieties & $\begin{array}{c}\text { Grain Yield } \\
\text { kg/ha }\end{array}$ & $\begin{array}{c}\text { Weight of } \\
\mathbf{1 0 0 0} \text { seed }(\mathbf{g})\end{array}$ & $\begin{array}{c}\text { Grain Weight } \\
\text { Spike }(\mathbf{g})\end{array}$ \\
\hline Arivat & $1898.0 \mathrm{c}$ & $42.467 \mathrm{a}$ & $2.207 \mathrm{a}$ \\
\hline Norma & $1583.0 \mathrm{~d}$ & $48.200 \mathrm{a}$ & $1.997 \mathrm{a}$ \\
\hline Iba99 & $2382.0 \mathrm{~b}$ & $50.967 \mathrm{a}$ & $2.293 \mathrm{a}$ \\
\hline NS313 & $2720.0 \mathrm{a}$ & $47.733 \mathrm{a}$ & $2.330 \mathrm{a}$ \\
\hline Bip999 & $2397.0 \mathrm{a}$ & $48.100 \mathrm{a}$ & $2.220 \mathrm{a}$ \\
\hline
\end{tabular}

Means followed by the same letter within a column are not significantly differenced according to Duncan's multiple range test at $\mathrm{p} \leq 0.05$.

Table 2: Means of spike length, average spike weights and number of grains/spike.

\begin{tabular}{cccc}
\hline Varieties & $\begin{array}{c}\text { Spike Length } \\
(\mathbf{c m})\end{array}$ & $\begin{array}{c}\text { Spike Weight } \\
(\mathbf{g})\end{array}$ & $\begin{array}{c}\text { No. of } \\
\text { grains/spike }\end{array}$ \\
\hline Arivat & $5.267 \mathrm{a}$ & $2.513 \mathrm{a}$ & $36.700 \mathrm{~d}$ \\
\hline Norma & $5.100 \mathrm{a}$ & $2.267 \mathrm{a}$ & $35.800 \mathrm{~d}$ \\
\hline Iba99 & $4.733 \mathrm{a}$ & $2.740 \mathrm{a}$ & $44.133 \mathrm{a}$ \\
\hline NS313 & $5.033 \mathrm{a}$ & $2.693 \mathrm{a}$ & $41.033 \mathrm{c}$ \\
\hline Bip999 & $4.600 \mathrm{a}$ & $2.563 \mathrm{a}$ & $42.267 \mathrm{~b}$ \\
\hline
\end{tabular}

Means followed by the same letter within a column are not significantly differenced according to Duncan's multiple range test at $\mathrm{p} \leq 0.05$.

It is indicated from the table (3) that plant length andhay yield traits with significant differences depending on the variety. Iba99 recorded highest plant length $(89.433 \mathrm{~cm})$ significantly different from the rest varieties. Norma was significantly with the shortest plants $(62.45 \mathrm{~cm})$. There were no significant differences among the tested varieties in the number of fertile tillers. Regarding hay yield, NS313recorded significantly the highest hay yield $3643.000 \mathrm{~kg} / \mathrm{ha}$. Variety Norma, recorded the lowest hay yield $\mathrm{kg} / \mathrm{ha}$ which was significantly different from variety NS313only. 
Table 3: The plant height, No. of fertile tiller and hay yield of the five studied varieties of barley.

\begin{tabular}{cccc}
\hline Varieties & $\begin{array}{c}\text { Plant Height } \\
(\mathbf{c m})\end{array}$ & $\begin{array}{c}\text { No. of Fertile } \\
\text { Tillers }\end{array}$ & $\begin{array}{c}\text { Hay Yield } \\
\text { kg/ha }\end{array}$ \\
\hline Arivat & $78.350 \mathrm{c}$ & $2.133 \mathrm{a}$ & $3202.000 \mathrm{ab}$ \\
\hline Norma & $62.450 \mathrm{e}$ & $2.133 \mathrm{a}$ & $2569.333 \mathrm{~b}$ \\
\hline Iba99 & $89.433 \mathrm{a}$ & $2.033 \mathrm{a}$ & $2861.333 \mathrm{ab}$ \\
\hline NS313 & $72.667 \mathrm{~d}$ & $1.900 \mathrm{a}$ & $3643.000 \mathrm{a}$ \\
\hline Bip999 & $86.067 \mathrm{~b}$ & $1.667 \mathrm{a}$ & $2956.333 \mathrm{ab}$ \\
\hline
\end{tabular}

Means followed by the same letter within a column are not significantly differenced according to Duncan's multiple range test at $\mathrm{p} \leq 0.05$.

Table (4) represents the results of straw and hay cost, grain and hay cost and hay revenue traits. The studied varieties were significantly different in straw and hay cost. Varieties Norma recorded the lowest straw and hay cost (231.480), whereas variety NS313 recorded the highest straw and hay cost (336.095) whereas the rest varieties were not significantly different. In terms of grain and hay cost, variety Norma recorded the lowest grain and hay cost (631.180) which was not significantly different from varieties Arivat, Iba99 and Bip999. Variety NS313 recorded the highest grain and hay cost (736.180) and it was not significantly different from varieties 1, 3 and 5, regarding hay revenue. Variety NS313 recorded the highest hay revenue (1000 ID/ha), (582.880) which was significantly different from No. 1 only. Variety Norma recorded lowest hay revenue (421.547).

Table 4: The straw and hay cost, grain and hay cost and revenue of five varieties of barley.

\begin{tabular}{cccc}
\hline Varieties & $\begin{array}{c}\text { Straw and Hay } \\
\text { Cost (1000 } \\
\text { ID/ton) }\end{array}$ & $\begin{array}{c}\text { Grain and Hay } \\
\text { Cost (1000 } \\
\text { ID/ha) }\end{array}$ & $\begin{array}{c}\text { Hay Revenue } \\
\text { (1000 ID/ha) }\end{array}$ \\
\hline Arivat & $288.180 \mathrm{ab}$ & $688.180 \mathrm{ab}$ & $512.320 \mathrm{~b}$ \\
\hline Norma & $231.480 \mathrm{~b}$ & $631.180 \mathrm{~b}$ & $421.547 \mathrm{ab}$ \\
\hline Iba99 & $258.187 \mathrm{ab}$ & $657.520 \mathrm{ab}$ & $457.813 \mathrm{ab}$ \\
\hline NS313 & $336.090 \mathrm{ab}$ & $736.180 \mathrm{a}$ & $582.880 \mathrm{ab}$ \\
\hline Bip999 & $266.070 \mathrm{ab}$ & $666.070 \mathrm{ab}$ & $473.013 \mathrm{a}$ \\
\hline
\end{tabular}

Means followed by the same letter within a column are not significantly differenced according to Duncan's multiple range test at $\mathrm{p} \leq 0.05]$.

Data represented in the table (5) showed that these varieties were significantly different in grain revenue and profit $1000 \mathrm{ID} / \mathrm{ha}$ at 0.05 level of significance. In terms of grain revenue, variety NS313recorded the highest grain revenue (1019.997) for $1000 \mathrm{ID} / \mathrm{ha}$. Regarding total hay and grain revenue, there was no significant difference between the five tested varieties. For the trait profit $1000 \mathrm{ID} /$ ha, variety NS313recorded the highest profit 1000 ID/ha, (866.697), which was significantly different from variety Norma only. Variety NS313recorded the highest grain revenue, profit 1000 ID/ha and total hay and grain revenue.
Table 5: Grain revenue, total hay and grain revenue and profit 1000 ID/ha.

\begin{tabular}{cccc}
\hline Varieties & $\begin{array}{c}\text { Grain } \\
\text { Revenue 1000 } \\
\text { ID/ha }\end{array}$ & $\begin{array}{c}\text { Total Hay and } \\
\text { Grain Revenue } \\
\text { 1000 ID/ha }\end{array}$ & $\begin{array}{c}\text { Profit 1000 } \\
\text { ID/ha }\end{array}$ \\
\hline Arivat & $711.750 \mathrm{ab}$ & $1224.027 \mathrm{a}$ & $469.223 \mathrm{ab}$ \\
\hline Norma & $593.620 \mathrm{~b}$ & $1015.167 \mathrm{a}$ & $383.653 \mathrm{~b}$ \\
\hline Iba99 & $893.247 \mathrm{ab}$ & $1351.060 \mathrm{a}$ & $693.540 \mathrm{ab}$ \\
\hline NS313 & $1019.997 \mathrm{a}$ & $1602.727 \mathrm{a}$ & $866.69 \mathrm{a}$ \\
\hline Bip999 & $898.875 \mathrm{ab}$ & $1371.887 \mathrm{a}$ & $691.367 \mathrm{ab}$
\end{tabular}

Means followed by the same letter within a column are not significantly differenced according to Duncan's multiple range test at $\mathrm{p} \leq 0.05$.

There were significant differences among the studied varieties concerning ID income and Seed productivity $\mathrm{kg} / \mathrm{ha}$, table (6).Variety NS313, significantly recorded the highest seed yield of $(2720 \mathrm{~kg} / \mathrm{ha})$ and ID income (2.21) which was different from variety Norma, while, in term of cost revenue no significant differences were found among the varieties.

Table 6: The seed product, ID/income and cost/revenue of five varieties of barley.

\begin{tabular}{cccc}
\hline Varieties & $\begin{array}{c}\text { Seed Productivity } \\
\text { kg/ha }\end{array}$ & ID Income & Cost/Revenue \\
\hline Arivat & $1898 \mathrm{ab}$ & $1.778 \mathrm{ab}$ & $0.562 \mathrm{a}$ \\
\hline Norma & $1583 \mathrm{~b}$ & $1.588 \mathrm{~b}$ & $0.639 \mathrm{a}$ \\
\hline Iba99 & $2382 \mathrm{ab}$ & $2.098 \mathrm{ab}$ & $0.501 \mathrm{a}$ \\
\hline NS313 & $2720 \mathrm{a}$ & $2.210 \mathrm{a}$ & $0.46 \mathrm{a}$ \\
\hline Bip999 & $2397 \mathrm{ab}$ & $2.056 \mathrm{ab}$ & $0.495 \mathrm{a}$ \\
\hline
\end{tabular}

Means followed by the same letter within a column are not significantly differenced according to Duncan's multiple range test at $\mathrm{p} \leq 0,05]$.

\section{CONCLUSION}

From the result of this study it can be concluded that varieties No.4 and No.5 were among the superior varieties in terms of grain weight per spike, spike length, spike weight, hay yield, number of fertile tillers, straw and hay cost, grain, and hay cost, hay revenue, grain revenue, profit 1000ID/ha, seed product, ID income and seed yield. On the light of the results of this study, we recommend growing varieties No.4 and No.5 for their superiority in the majority of the tested traits in this study or in most of the agronomy characters and in terms of economic aspect. The economic and technical feasibility study and economic performance of agricultural projects are very important in developing countries before and after starting the production process to ensure the success of the project and its profitability. The farmers in the Kurdistan region of Iraq did not take care of this study at all, do not count the costs, production, revenue and profit. They do not care about the selection of improved varieties, seed production, planting time, seeding rate, fertilizing, types of barley, time of barley seeding, date of cultivation, tillage, as well as crop service operation from irrigation, weeding. Most of the farmers plant barley just for its grain and they leave the straw or burn it in the field instead of collecting and turning it into hay to use it for animal feed in winter or selling it to reduce the proportion of production costs to its imports and increase the profitreducing the loss if any. 


\section{REFERENCES}

[1] FAOSTAT of the United Nations food and agriculture organization, statistics division 1997, 2014.

[2] Central statistical organization, agricultural statistics directorate. Cso , report on wheat and barley production in Iraq for 2015 . October. Page 13-16, 2015.

[3] A. Badr, K. Müller, R. Schäfer-Pregl, H. E. Rabey, S. Effgen, , H. H.Ibrahim, F. Salamini,. "On the origin and domestication history of barley Hordeumvulgare," Molecular Biology and Evolution, 17, 499-510, 2000.

[4] D.Hales. "Eat smart, feed good and look great digest," New York Vol. 8, No, 63, 1992.

[5] KRSO: kurdistan region statistics office ministry of planning, p.18, 2014

[6] T. Nordblom, H. Halimeh, "Lentil crop residues make a difference," communication department, ICARDA, P.O. Box 5466, Aleppo, Syria NO, 9, pp. 9-10, 1982.

[7] R. E. Altona,"Urea and biuretasprotein sipplementsforrange cattle sheep in Africa Outlook on agriculture," Vol.5:22-27, B., 1966.

[8] A. R. Staniforth, "Straw for Fuel, Feed and Fertiliser," Ipswich", UK: Farming Press, 1982.

[9] J. Kelley, "Upgrading of waste cereal straws Outlook on Agriculture," Vol. 21:105-108, 1992.

[10] N. Alexandratos, "World Agriculture towards 2010," FAORome and John Wiley and Sons: Chichester, 1995.

[11] V. L. Kossila, "Location and potential feed use in Straw and other Fibrous By-products as Feed," Developments in Animal and Veterinary Sciences, 14. Elsevier, Amsterdam, 431-453, 1984.

[12] T. G. Kelley, P. P. Rao," Yield and quality characteristics of improved and traditional sorghum cultivars: farmer sperceptions and preferences,". InVariation in the Quantity and Quality of Fibrous Crop Residues, 133-145, Eds, 1994.

[13] P. T. Doyle, C. Devendra, and G. R. Pearce, "Rice Straw as a Feed for Ruminants". International Development Program of Australian Universities and Colleges (IDP): Canberra, 1986.

[14] B. S. Capper, E. F. Thomson, S. Rihawi, A. Termanini, R. Macrae," The feeding value of straw from different genotypes of barley when given to Awassi sheep," Animal Production 42:337-342, 1986.

[15] B. S. Capper, E. F Thomson and F. Herbert, "Genetic variation in the feeding value of barley and wheat straw. In Plant Breeding and the Nutritive Value of Crop Residues," (Eds J. D. Reed, B. S. Capper and P. J. H. Neate). International Livestock Centre for Africa, Addis Ababa, Ethiopia, 7-10 Dec, pp.177$192,1987$.

[16] B. S. Capper, E. F. Thomson, S. Rihawi, "Voluntary intake and digestibility of barley straw as influenced by variety and supplementation with either barley grain or cottonseed cake," Animal Feed Science and Technology Vol. 26:105-118, 1989

[17] B. S., Capper, E. F., Thomson, S., Rihawi, A. Termanini, and R. Macrae, "The feeding value of straw from different genotypes of barley when given to Awassi sheep. Animal Production 42:337342, 1986

[18] B.S.Capper,Thomson,E.F.andHerbert,F,"'Geneticvariationinthefe edingvalueofbarleyandwheatstraw. In Plant Breeding and the Nutritive Value of Crop Residues, 177-192 (Eds J. D. Reed, B. S. Capper and P. J. H. Neate). International Livestock Centre for Africa, Addis Ababa, Ethiopia, 7-10, 1987, 1988.

[19] B. S., Capper, E. F. Thomson, and Rihawi, S. "Voluntary intake and digestibility of barley straw as influenced by variety and supplementation with either barley grain or cottonseed cake." Animal Feed Science and Technology 26:105-118, 1989.

[20] B. S., Capper, G., Sage, P. R. Hanson, and A. H. Adamson, "Influence of variety, row type and time of sowing on the morphology, chemical composition and in vitro digestibility of barley straw." Journal of Agricultural Science, Cambridge 118:165-173,1992.

[21] J.D.,Reed,B.S.Capper,andNeate,P.J.H.,'PlantBreedingandtheNu tritiveValueofCropResidues.Proceedings of a workshop held at the International Livestock Centre for Africa" Addis Ababa, Ethiopia, 1987.

[22] J. B., Schiere, A. J. Nell, and M. N. M. Ibrahim, "Feeding of urea-ammonia treated rice straw." World Animal Review 65:3142, 1988.

[23] E. R., Shand, W. J., Tedesco, D. and Morrice, L. A. F. "Rumen degradation of straw 10. Consistency of differences in nutritive value between varieties of cereal straws." Animal Production $51: 155-16, .1990$.

[24] S. Kiran and J. B. Schiere. "Feeding of ruminants on fibrous crop residues. Proceedings of an international workshop held at the National Dairy Research Institute, Karnal, India.” Indian Council of Agricultural Research, Krishi Bhavan, New Delhi, India.

[25] D.B Duncan, "Multiple Range and Multiple F.test." Biometrics, 11:1-42.,1955 